\title{
Pengaruh Keterampilan Bidan Konseling Berdasar Health Belief Model (HBM) Pada Ibu Terhadap Perubahan Perilaku Penanganan Balita Diare Tanpa Dehidrasi
}

\author{
Elvina Indah Syafriani ${ }^{1}$, Desi Hariani ${ }^{2}$ \\ STIK Siti Khadijah Palembang, ${ }^{12}$
}

\section{A B S T R A K}

Informasi Artikel :

Diterima : 31 Maret 2021

Direvisi : 15 April 2021

Disetujui : 29 Mei 2021

Diterbitkan : 15 Juni 2021

"Korespondensi Penulis : vivinsyaiful@gmail.com

Untuk menurunkan angka kematian dan angka kesakitan balita karena diare diperlukan strategi efektif yang dapat merubah perilaku ibu dalam merawat balita sakit diare, yaitu melalui keterampilan konseling oleh tenaga kesehatan. Tujuan penelitian ini adalah untuk menganalisis pengaruh keterampilan konseling bidan berdasar Health Belief Model (HBM) pada ibu terhadap perubahan perilaku penanganan balita diare tanpa dehidrasi. Penelitian ini quasi eksperimental dengan Pre-Post test control Group Design. Sampel dalam penelitian ini adalah ibu balita diare tanpa dehidrasi yang memenuhi kriteria inklusi dengan 65 responden kelompok perlakuan dan 65 responden kelompok kontrol. Analisis data dengan menggunakan uji komparatif numerik dan kategorik. Perbedaan rerata dianalisis dengan uji MannWhitney tidak berpasangan dan uji Wilcoxon berpasangan, dengan kemaknaan hasil uji ditentukan berdasarkan nilai $\mathrm{p}<0,05$. Hasil penelitian didapatkan bahwa peningkatan keterampilan konseling bidan pada kelompok perlakuan lebih tinggi bila dibandingkan kelompok kontrol $(\mathrm{p}<0,05)$. Peningkatan nilai perubahan perilaku penanganan pada kelompok perlakuan lebih tinggi bila dibandingkan kelompok kontrol $(\mathrm{p}<0,05)$. Keterampilan bidan konseling berdasar Health Belief Model (HBM) berpengaruh terhadap perubahan perilaku penanganan balita diare tanpa dehidrasi.

Kata Kunci : Balita diare tanpa dehidrasi, Health Belief Model (HBM) dan keterampilan konseling

\begin{abstract}
To reduce mortality and morbidity of children under five with diarrhea need effective strategies to change the behavior of a mother in caring for sick infants diarrhea, namely through counseling by health personnel. The purpose of this study was to analyze the effect of skill of counseling a midwife based on the Health Belief Model (HBM) on mother to behavioral change handling of toddler diarrhea without dehydration. This quasi experimental study with Pre-Post test Control Group Design. The sample in this study was diarrhea without dehydration mothers who met the inclusion criteria with 65 respondents treatment group and the control group of 65 respondents. Data analysis using comparative test of numerical and categorical. Mean difference was analyzed with the MannWhitney unpaired and paired Wilcoxon test, with a significance test results are determined based on the value of $p<0.05$. The results showed that the improvement in the skills of counseling midwives to treatment group was higher when compared to the control group $(p<0,05)$. Increasing the value of behavior change treatment in the treatment group was higher when compared to the control group $(p<0.05)$. skill of counseling a midwife based on the Health Belief Model (HBM)to affect the increased change the behavior of toddlers handling of diarrhea without dehydration
\end{abstract}

Keywords: Toddlers diarrhea without dehydration, Health Belief Model $(H B M)$ and skill of counseling 


\section{PENDAHULUAN}

Derajat kesehatan merupakan salah satu unsur penting dalam upaya peningkatan Indeks Pembangunan Manusia (IPM) bangsa Indonesia. Sementara itu, derajat kesehatan tidak hanya ditentukan oleh pelayanan kesehatan, tetapi yang lebih dominan justru adalah kondisi lingkungan dan perilaku masyarakat. Upaya untuk mengubah perilaku masyarakat agar mendukung peningkatan derajat kesehatan dilakukan melalui program pembinaan Perilaku Hidup Bersih dan Sehat (PHBS).(Kemenkes, 2011)

Masalah kesehatan yang dapat ditimbulkan dari kurangnya kesadaran masyarakat dalam penerapan PHBS salah satunya adalah masih tingginya prevalensi penyakit infeksi dimasyarakat antara lain Infeksi Saluran Pernapasan Akut (ISPA), pneumonia, diare, hepatitis, malaria dan DBD.(Kemenkes, 2013)

Diare adalah penyebab utama kesakitan dan kematian anak-anak dibawah usia 5 tahun di seluruh dunia. Anak kecil sangat rentan terhadap penyakit diare dan proporsi kematian tinggi terjadi dalam 2 tahun pertama kehidupan. Diseluruh dunia, mayoritas kematian terkait dengan diare terjadi di Afrika dan Asia Selatan. Hampir setengah dari kematian karena diare terjadi pada anak di Afrika dimana diare adalah penyebab terbesar kematian dikalangan anak dibawah usia 5 tahun dan penyebab utama dari penyakit masa kanak-kanak.(Mengistie, 2013)

Studi epidemiologi menunjukkan bahwa faktor-faktor yang menentukan terjadinya diare pada anak usia dibawah 5 tahun begitu kompleks dan faktor yang berkontribusi relatif bervariasi tergantung pada negara, daerah dan masyarakat, sebagai contoh pengaruh yang timbul dari faktor sosial ekonomi, lingkungan dan perilaku. Intervensi pada setiap faktor terjadinya diare akan berguna untuk mencegah kematian dari diare.(Nhampossa, 2015) Hal tersebut akan membantu dalam strategi perencanaan dan pelaksanaan pencegahan ditingkat

masyarakat. Pengetahuan masyarakat sangat penting untuk menginformasikan program pencegahan dan pengendalian penyakit diare.(O'reilly, 2012)

Didunia, sebanyak 6 juta anak meninggal setiap tahun karena diare. Penyakit diare masih menjadi masalah kesehatan khususnya dinegara berkembang. Indonesia adalah salah satu negara berkembang yang memiliki morbiditas dan mortalitas diare yang masih tinggi. Berdasarkan laporan World Health Organization (WHO), kematian karena diare di Indonesia sudah menurun akan tetapi angka kesakitan karena diare masih tinggi.(Kemenkes, 2011) Insiden terjadinya diare di Indonesia berdasarkan karakteristik penduduk dilihat dari hasil laporan Riset Kesehatan Dasar (RISKESDAS) tahun 2013 untuk seluruh kelompok umur di Indonesia adalah 3.5\%. Terbanyak pada balita sebesar $7,6 \%$, pada kelompok usia 12-23 bulan, lalu kelompok usia 24-35 bulan sebesar 5,8\% dan kelompok usia 0-11 bulan sebesar 5,5\% dan terjadi didaerah pedesaan. Berdasarkan hasil survey tersebut dapat disimpulkan bahwa balita termasuk kelompok umur yang berisiko terkena diare di Indonesia.

Jumlah kasus diare di Sumatera Selatan tahun 2013 mencapai 188.028 penderita dengan insiden rate $4,5 \%$, diantaranya adalah kasus diare pada balita sebanyak 51.820 penderita dan tertinggi di kota Palembang.(Dinkes Sumsel, 2013) Hal ini menunjukkan bahwa kasus diare pada balita masih tetap tinggi dibandingkan golongan umur lainnya. Berdasarkan profil kesehatan kota Palembang 2014 penderita diare sebagian besar berobat jalan ke Puskesmas.

Perubahan perilaku terjadi akibat hasil dari intervensi atau adanya pembelajaran dari peristiwa yang dapat mengurangi atau menggerakan fisiologis seseorang dan perubahan perilaku juga terjadi dengan adanya frekuensi yang berulang dalam pemberian informasi (reinforcements) dan hal ini juga dipengaruhi dengan adanya reward/penghargaan atas apa yang telah dilakukan.(Glanz, 2008) 
Promosi perubahan perilaku adalah alat utama pada intervensi non klinis yang bertujuan untuk mengurangi kesakitan dan kematian anak. Kebijakan disusun untuk mengatasi penyakit diare yang fokusnya pada ibu yang memiliki anak balita, dan juga termasuk pelatihan tenaga kesehatan.(Sequiin, 2015)

Untuk meningkatkan perilaku ibu dalam merawat balitanya yang sakit WHO merancang strategi dalam pendidikan kesehatan yang berupa konseling. Konseling disini merupakan suatu upaya untuk menciptakan perilaku masyarakat yang kondusif bagi kesehatan. Artinya konseling yang ditujukan pada ibu dapat menciptakan perilaku yang kondusif untuk kesehatan anaknya. Hal ini sesuai dengan penelitian yang dilakukan tahun 2012 dimana hasilnya pemberian konseling pada ibu berpengaruh terhadap perilaku ibu dalam merawat balita sakit diare.(Puspitasari, 2011) Hasil yang sama juga sesuai dengan panduan sosialisasi tatalaksana diare menurut Kementerian Kesehatan (Kemenkes) yang menyatakan bahwa pentingnya konseling dalam tatalaksana diare oleh tenaga kesehatan. Teknik konseling yang sesuai akan mempengaruhi keterampilan komunikasi yang baik dari petugas kesehatan sehingga membantu ibu melakukan penanganan diare pada balita saat dirumah.(Kemenkes, 2011)

Pencegahan dan pengobatan diare tanpa dehidrasi atau ringan bisa ditangani sendiri dirumah. Peran keluarga dalam menangani diare sangat penting, terutama keluarga yang paling dekat dengan balita yaitu ibu dituntut untuk mengetahui dan terampil menangani penyakit diare. Pada balita, ibu perlu mengetahui serta mengamati tanda keluhan dini diare dan kapan mencari pertolongan ke fasilitas pelayanan kesehatan yang memadai agar penyakit tidak bertambah berat. Perilaku ibu dapat berpengaruh terhadap diare dari ringan menjadi berat sehingga dapat berakibat kematian dan munculnya komplikasi lain, diantaranya gangguan pertumbuhan yang terjadi pada diare kronis. Pada balita dengan diare kronis sangat rentan terjadinya penurunan berat badan karena kekurangan cairan yang berlarut larut termasuk gagalnya asupan nutrisi dapat menimbulkan komplikasi lain dan kematian, gangguan nutrisi dan pertumbuhan. Perilaku ibu dalam merawat balita sakit diare sangat penting untuk mencegah komplikasi yang akan terjadi apabila perilaku ibu kurang tepat.(Maryunani, 2017)

Upaya penyuluhan kesehatan yang selama ini dilakukan oleh bidan lebih ditekankan kepada penyuluhan kelompok/penyuluhan massa dengan tujuan agar masyarakat tahu, paham dan diharapkan merubah perilaku ke arah kesehatan yang baik. Sampai saat ini kegiatan tersebut kurang efektif karena kurangnya pengulangan informasi (reinforcements). Selain kegiatan tersebut, konseling individu dapat dilakukan pada setiap pelayanan oleh tenaga kesehatan (bidan). Sehingga pendekatan melalui konseling individu tersebut dapat membantu untuk memecahkan suatu masalah yang dihadapi seseorang yang akan diatasi sendiri sesuai dengan keputusan yang diambilnya setelah melalui konseling.(Kusuma,2009)

Beberapa penelitian tentang kualitas konseling menunjukkan kurang adekuatnya informasi yang diberikan selama konseling berlangsung, konseling hanya sekedar sharing, bukan informasi yang direkomendasikan sesuai pedoman konseling balita diare tanpa dehidrasi. Data yang ada menunjukkan bahwa pengetahuan pasien menjadi kurang karena komunikasi dalam konseling yang masih rendah.(Beck,2002)

Konseling balita diare yang sudah dilakukan saat ini oleh bidan masih belum meningkatkan perilaku penanganan balita diare tanpa dehidrasi dirumah, terbukti masih banyak ibu yang melakukan kunjungan ulang pada sarana kesehatan untuk mendapatkan penanganan kembali pada anaknya dikarenakan belum menunjukkan perbaikan, kondisi memburuk bahkan perlu mendapatkan perawatan di rumah sakit. Hasil Penelitian yang dilakukan oleh Retno di Provinsi DIY mengenai pelaksanaan 
konseling, 25 bidan mengartikan konseling sebagai pemberian informasi untuk meningkatkan pengetahuan, sedangkan 9 bidan mengartikan konseling sebagai proses pemecahan masalah dan 4 bidan mengartikan konseling dengan memberikan informasi,edukasi dan membantu ibu menyelesaikan masalah yang dihadapi. Data tersebut terlihat bahwa pengetahuan bidan tentang konseling masih kurang dan hanya sekedar memberikan informasi yang didominasi oleh bidan dan waktu yang digunakan rata-rata 5-10 menit. Informasi yang disampaikan oleh bidan hanya sebatas menjawab keluhan ibu saja,sehingga masih banyak informasi yang belum diberikan. Hal ini menunjukkan bahwa bidan belum memahami benar tentang konseling pada ibu balita diare.

Berdasarkan hasil studi pendahuluan diketahui kurang efektifnya konseling dan media bantuan konseling yang dilakukan bidan mengenai penyakit diare balita. Perilaku ibu masih kurang tepat yang disebabkan oleh ibu tidak dapat mengikuti anjuran konseling penanganan balita diare tanpa dehidrasi atau ringan dirumah dan pencegahan komplikasi yang diberikan. Hal ini dipengaruhi karena kurang efektifnya konseling akan penyampaian yang sesuai dengan masalah ibu dan kurangnya penguatan serta pengulangan kembali informasi yang diberikan (reinforcement). Perlu diperhatikan konseling dipengaruhi juga oleh bahasa dan pendidikan ibu, Oleh karena itu konselor atau bidan penting mengetahui metode konseling dengan pendekatan teori perubahan perilaku untuk dapat merubah perilaku dan keyakinan diri ibu. Bidan juga perlu meningkatan pengetahuan dan kepercayaan dirinya akan keterampilan mengenai penanganan standar diare balita tanpa dehidrasi dirumah. Maka dari itu perlu dicari alternatif penatalaksanaan diare dirumah dengan cara meningkatkan pendidikan ibu melalui informasi yang diberikan bidan agar efektif lewat konseling dengan media bantuan konseling. Hal ini juga didukung oleh penelitian tahun 2010 dimana adanya peningkatan pengetahuan dan sikap ibu terhadap penatalaksanaan diare pada balita setelah diberikan pendidikan kesehatan dengan media audiovisual.(Kapti, 2013)

Ibu yang memiliki anak balita perlu diberi keyakinan atau kepercayaan individu akan persepsi dari penyakit diare, agar terbentuk perilaku ibu yang dapat dilakukan dirumah pada saat anak mengalami diare dan dapat mencegah pada keadaan komplikasi. Hal ini dapat dilakukan secara berkala sehingga ibu tidak lupa dan dapat meningkatkan keyakinan atau kepercayaan diri ibu akan tindakan yang dapat diambil dalam menangani dan mencegah komplikasi diare. Perubahan perilaku tersebut dapat dibangun berdasar kajian teori Health Belief Models (HBM) yang dikembangkan oleh Glanz.

Model HBM menjelaskan tentang bagaimana membentuk perilaku sehat yang disampaikan lewat kepercayaan individu (ibu) melalui persepsi kerentanan dan keparahan penyakit, isyarat untuk melakukan tindakan, efikasi diri, manfaat dan hambatan. Sasarannya adalah kognisi ibu yang dapat merubah cara berpikir sehingga perilaku ibu berubah. Aplikasi ini terbukti efektif pada upaya perubahan perilaku wanita melalui skrining kanker payudara, kanker korolektal dan perilaku seksual berisiko.

Aplikasi konseling berdasar HBM terdapat pada penelitian mengenai HIV dimana melalui konseling dapat berpengaruh terhadap persepsi individu dalam melakukan pencegahan penyakit atau pada perubahan perilaku kearah perilaku yang lebih sehat.(Mola, 2016) Hasil yang sama juga ditemukan pada penelitian model konsep keperawatan HBM dimana dalam konsep ini faktor perilaku dan sosiodemografi ibu mempengaruhi ibu untuk melakukan tindakan pencegahan yaitu melakukan perilaku hidup bersih dan sehat dalam meminimalkan diare balita.(Nuraeni, 2012) Setiap persepsi yang baik mempengaruhi tingkat pengetahuan ibu yang tercermin 
dalam sikap dan tindakan yang dilakukan ibu pada pencegahan terjadinya diare.

Konseling berdasarkan teori Health Belief Model merupakan salah satu cara merubah persepsi dan keyakinan klien terhadap kesehatannya. Serta dapat merubah persepsi tenaga kesehatan akan pentingnya meningkatkan kepercayaan diri dalam memberikan informasi mengenai diare balita pada ibu sesuai dengan standar.(Riauwi,2014)

Dengan metode konseling diharapkan dapat menolong ibu untuk memahami dan menjelaskan pandangan ibu terhadap kehidupannya serta membantu mencapai tujuan penentuan diri (self determination). Ibu melalui pilihan yang telah diinformasikan dengan baik dan bermakna dapat memecahkan masalah yang dihadapi.(Mcleod, 2016)

Konseling penanganan balita diare dapat lebih efektif apabila berdasarkan teori perubahan perilaku yang salah satunya dengan HBM. Ibu balita akan memprediksi berdasarkan persepsi ibu yang diperoleh lewat informasi dan pemecahan masalah yang disampaikan oleh bidan untuk melakukan tindakan pencegahan, deteksi dan mengontrol kondisi sakit anak dengan diare, yang dapat diatasi oleh ibu dirumah sebagai bentuk perilaku sehat dalam mengatasi diare balita tanpa dehidrasi.

Berdasarkan latar belakang tersebut, dapat dirumuskan masalah utama penelitian adalah perilaku ibu dalam penatalaksanaan diare di rumah tangga belum menunjukkan perbaikan dan belum sesuai harapan, rendahnya persepsi ibu mengenai penanganan diare balita, menyebabkan belum efektifnya tatalaksana diare yang sesuai standar serta konseling bidan yang kurang optimal. Konseling bidan belum memfasilitasi ibu untuk mendapatkan persepsi yang baik sebagai informasi dalam meningkatkan kemampuan penanganan balita dengan diare tanpa dehidrasi yang berdampak pada keberhasilan penatalaksanaan balita diare tanpa dehidrasi dirumah.

\section{METODE PENELITIAN}

Rancangan yang digunakan dalam penelitian ini adalah Quasi Experimental dengan pre post control group design. Desain ini menggunakan dua kelompok penelitian yaitu kelompok perlakuan dan kelompok kontrol. Pada kelompok perlakuan akan diberikan konseling berdasar Health Belief Model (HBM) pada ibu balita diare tanpa dehidrasi sedangkan pada kelompok kontrol menggunakan konseling konvensional.

Sebelum melakukan penelitian, terlebih dahulu diadakan pelatihan konseling untuk bidan yang bekerja pada Puskesmas perlakuan. Tujuan dari pelatihan adalah untuk mengajarkan atau memperkenalkan kepada bidan kelompok perlakuan tentang penerapan konseling berdasar Health Belief Model (HBM) pada ibu balita diare tanpa dehidrasi yang tersusun dalam modul konseling balita diare.

Subjek penelitian ini adalah seluruh ibu yang mempunyai anak balita usia 1-5 tahun yang memenuhi kriteria inklusi dan bersedia mengikuti penelitian. Jumlah sampel sebanyak 65 ibu balita pada masing-masing kelompok penelitian. Pemilihan subjek dengan teknik consecutive sampling.

Subjek penelitian ini memiliki kriteria inklusi yaitu Ibu yang mempunyai anak balita diare tanpa dehidrasi yang datang memeriksakan balitanya ke puskesmas penelitian.

Instrumen yang digunakan adalah lembar observasi keterampilan konseling bidan. Pengujian statistik penelitian ini menggunakan analisis nonparametrik (uji Mann whitney), dengan kemaknaan hasil uji ditentukan berdasarkan nilai $\mathrm{p}<0,05$.

\section{HASIL PENELITIAN}

\section{Karakteristik Subjek Penelitian}

Karakteristik pada subjek penelitian disajikan untuk mengetahui kesetaraan antara kelompok perlakuan dan kontrol pada awal penelitian. Kedua kelompok dibandingkan yaitu meliputi umur, tingkat pendidikan, pekerjaan penghasilan dan pengetahuan. 
Jurnal Kebidanan : Jurnal Medical Science Ilmu Kesehatan Akademi Kebidanan Budi Mulia Palembang Volume.11 No.1, Juni 2021

Available online http://journal.budimulia.ac.id/

Tabel 1 Karakteristik Ibu Balita Pada Kedua Kelompok Penelitian

\begin{tabular}{|c|c|c|c|}
\hline \multirow[b]{2}{*}{ Karakteristik } & \multicolumn{2}{|c|}{ Kelompok } & \multirow[b]{2}{*}{$\begin{array}{l}\text { Nilai } \\
\mathbf{p}^{*}\end{array}$} \\
\hline & $\begin{array}{l}\text { Perlakuan } \\
(n=65)\end{array}$ & $\begin{array}{l}\text { Kontrol } \\
(\mathrm{n}=65)\end{array}$ & \\
\hline \multicolumn{3}{|l|}{ 1. $\begin{array}{l}\text { Umur } \\
\text { (tahun) }\end{array}$} & 0,220 \\
\hline$<20$ tahun & 0 & 1 & \\
\hline 20-29 tahun & 52 & 57 & \\
\hline$\geq 30$ tahun & 13 & 7 & \\
\hline Pendidikan & & & 0,304 \\
\hline PT & 9 & 9 & \\
\hline SMA & 44 & 50 & \\
\hline SMP & 12 & 6 & \\
\hline 3. Pekerjaan & & & 0,816 \\
\hline Bekerja & 12 & 10 & \\
\hline $\begin{array}{l}\text { Tidak } \\
\text { bekerja }\end{array}$ & 53 & 55 & \\
\hline \multirow[t]{6}{*}{ 4. Penghasila } & & & 0,822 \\
\hline & 52 & 54 & \\
\hline & & & \\
\hline & 13 & 11 & \\
\hline & & & \\
\hline & & & 0,910 \\
\hline
\end{tabular}

5. Pengetahua 52,62(9,23 52,77(8,751

$\mathrm{n}$

Mean (SD)

Median

3)

50

40-70

40-70

Rentang

Keterangan : *) Berdasarkan uji chi-kuadrat

Berdasarkan tabel 1 didapatkan bahwa tidak ada perbedaan yang bermakna $(p>0,05)$ pada kedua kelompok.

Tabel 2. Karakteristik Bidan Pada Kedua Kelompok Penelitian

\begin{tabular}{|c|c|c|c|}
\hline \multirow[b]{2}{*}{ Karakteristik } & \multicolumn{2}{|c|}{ Kelompok } & \multirow[b]{2}{*}{$\begin{array}{l}\text { Nilai } \\
\text { p* }\end{array}$} \\
\hline & $\begin{array}{l}\text { Perlakuan } \\
(n=18)\end{array}$ & $\begin{array}{l}\text { Kontrol } \\
(n=18)\end{array}$ & \\
\hline $\begin{array}{l}\text { 1. Umur } \\
\text { (tahun) }\end{array}$ & & & 0,697 \\
\hline Mean (SD) & $34,11(4,8)$ & $34,22(4)$ & \\
\hline Rentang & $28-45$ & $28-43$ & \\
\hline $\begin{array}{l}\text { 2. Masa Kerja } \\
\text { (tahun) }\end{array}$ & & & 0,732 \\
\hline Mean (SD) & $9,72(4,12)$ & $8,06(3,4)$ & \\
\hline $\begin{array}{l}\text { Median } \\
\text { (rentang) }\end{array}$ & $9,50(4-17)$ & $8(3-15)$ & \\
\hline
\end{tabular}

Keterangan : *) Berdasarkan uji chi-kuadrat

Berdasarkan tabel 2 didapatkan bahwa tidak ada perbedaan yang bermakna $(p>0,05)$ pada kedua kelompok.

\section{Perbedaan Peningkatan Keterampilan Bidan Konseling Sebelum dan Sesudah Penelitian}

Untuk mengetahui perbedaan peningkatan keterampilan bidan konseling sebelum dan sesudah penelitian, maka peneliti melakukan analisis terhadap data skor keterampilan sebelum dan sesudah sebagaimana tercantum pada tabel berikut.

Tabel 3 Perbedaan Peningkatan Keterampilan Bidan Konseling Sebelum dan Sesudah Penelitian

\begin{tabular}{|c|c|c|c|}
\hline \multirow{2}{*}{$\begin{array}{l}\text { Keterampilan } \\
\text { Bidan } \\
\text { Konseling }\end{array}$} & \multicolumn{2}{|c|}{ kelompok } & \multirow{2}{*}{ Nilai $\rho$} \\
\hline & $\begin{array}{c}\text { Perlakuan } \\
(n=65)\end{array}$ & $\begin{array}{c}\text { Kontrol } \\
(n=65)\end{array}$ & \\
\hline $\begin{array}{ll}\text { a. } & \text { Sebelum } \\
& \text { Mean (SD) } \\
& \text { Median } \\
& \text { (Rentang) }\end{array}$ & $\begin{array}{l}47,6(3,52) \\
49(38-49)\end{array}$ & $\begin{array}{l}48,2(2,57) \\
49 \\
49)\end{array}$ & $0,938^{*}$ \\
\hline $\begin{array}{ll}\text { b. } & \text { Sesudah } \\
\text { Mean (SD) } \\
\text { Median } \\
\text { (Rentang) }\end{array}$ & $\begin{array}{l}79,3(7,37) \\
76,5(72- \\
98)\end{array}$ & $\begin{array}{l}52,1 \\
(2,65) \\
51,5 \quad(46- \\
58)\end{array}$ & $<0,001 *$ \\
\hline $\begin{array}{ll}\text { c. } & \text { Perubahan } \\
\text { (Pre-Post) } \\
\text { Mean (SD) } \\
\text { Median } \\
\text { (Rentang) } \\
\text { Nilai p }\end{array}$ & $\begin{array}{l}67,4(19,7) \\
59,8(47- \\
115) \\
<0,001 * *\end{array}$ & $\begin{array}{l}8,2(5,4) \\
6,2(0-21) \\
0,001^{* *}\end{array}$ & \\
\hline
\end{tabular}

Keterangan : *) Uji Mann Whitney **)Uji Wilcoxon

Berdasarkan tabel 3 menunjukkan bahwa nilai keterampilan konseling bidan setelah diberikan intervensi terdapat perbedaan yang bermakna pada kedua kelompok penelitian $(\mathrm{p}<0,05)$. Tabel menunjukkan bahwa nilai rata-rata peningkatan lebih besar pada kelompok perlakuan dibandingkan kelompok kontrol.

\section{Perbedaan Peningkatan Perilaku Penanganan Sebelum dan Sesudah Penelitian}


Untuk mengetahui perbedaan peningkatan perilaku penanganan yang diukur pada kedua kelompok sebelum dan sesudah penelitian, maka peneliti melakukan analisis terhadap perilaku penanganan yang tercantum pada tabel berikut.

\section{Tabel 4 Perbedaan Peningkatan Perilaku Penanganan Sebelum dan Sesudah Penelitian}

\begin{tabular}{|c|c|c|c|}
\hline \multirow{2}{*}{$\begin{array}{l}\text { Perilaku } \\
\text { penanganan }\end{array}$} & \multicolumn{2}{|c|}{ kelompok } & \multirow[t]{2}{*}{ Nilai $\rho$} \\
\hline & $\begin{array}{c}\text { Perlakuan } \\
(n=65)\end{array}$ & $\begin{array}{c}\text { Kontrol } \\
(n=65)\end{array}$ & \\
\hline $\begin{array}{ll}\text { a. } & \text { Sebelum } \\
& \text { Mean (SD) } \\
& \text { Median } \\
& \text { (Rentang) }\end{array}$ & $\begin{array}{l}38,38 \\
(4,866) \\
38(33-48)\end{array}$ & $\begin{array}{l}39,83 \\
(5,005) \\
38(33-52)\end{array}$ & $0,081 *$ \\
\hline $\begin{array}{ll}\text { b. } & \text { Sesudah } \\
\text { Mean (SD) } & \text { Median } \\
\text { (Rentang) }\end{array}$ & $\begin{array}{l}78,37 \\
(8,668) \\
76(62-95)\end{array}$ & $\begin{array}{l}42,35 \\
(5,776) \\
43(33-52)\end{array}$ & $<0,001 *$ \\
\hline $\begin{array}{ll}\text { c. } & \begin{array}{l}\text { Perubahan } \\
\text { (Pre-Post) }\end{array} \\
\text { Mean (SD) } & \text { Median } \\
\text { (Rentang) } & \text { Nilai p }\end{array}$ & $\begin{array}{l}39,9(9,2) \\
38(23-62) \\
<0,001 * *\end{array}$ & $\begin{array}{l}2,5(2,5) \\
4(0-5) \\
0,001 * *\end{array}$ & $<0,001 *$ \\
\hline
\end{tabular}

Keterangan : *) Uji Mann Whitney **)Uji Wilcoxon

Berdasarkan tabel 4 didapatkan bahwa terdapat perbedaan yang bermakna $(p<0,05)$ terhadap peningkatan perilaku penanganan pada kedua kelompok setelah dilakukan intervensi. Tabel menunjukkan bahwa nilai rata-rata peningkatan lebih besar pada kelompok perlakuan dibandingkan kelompok kontrol.

\section{PEMBAHASAN}

\section{Karakteristik Subjek Penelitian}

Karakteristik responden yang dilihat sebagai variabel perancu dalam penelitian ini adalah usia, pendidikan, pekerjaan, penghasilan dan pengetahuan. Berdasarkan tabel 1 diketahui bahwa karakteristik usia, pendidikan, pekerjaan dan penghasilan tidak berbeda secara bermakna pada kedua kelompok, yang ditunjukkan oleh nilai $\mathrm{p}$ hasil uji chi-kuadrat melebihi 0,05 sehingga dapat disimpulkan bahwa kedua kelompok memiliki karakteristik yang homogen sehingga layak untuk diperbandingkan.

Dilihat dari karakteristik usia, usia ibu balita berada pada rentang 20-29 tahun. Perbedaan yang tidak bermakna untuk usia subjek pada kedua kelompok penelitian memungkinkan adanya kesamaan kematangan emosional, pengalaman, dan informasi yang dimiliki subjek. Ibu yang usianya lebih tua diharapkan memiliki kematangan emosional yang lebih baik dalam menjalankan perannya sebagai seorang ibu. Usia juga dikaitkan dengan semakin banyaknya pengalaman dan informasi yang diperoleh sehingga dapat membangun konsep diri yang baik dan mampu menumbuhkan kepercayaan diri dalam melakukan kegiatan.

Responden penelitian memiliki latar belakang pendidikan yang tinggi yaitu Sekolah Menengah Atas (SMA) dan Perguruan Tinggi (PT). Berdasarkan data yang disajikan pada tabel 4.1 terlihat bahwa berdasarkan tingkat pendidikan tidak berbeda secara bermakna pada kedua kelompok, yang ditunjukkan oleh nilai $p$ yaitu 0,304 . Menurut hasil penelitian yang dilakukan Dennis (2006) yang menyatakan bahwa perempuan dengan pendidikan yang lebih baik memiliki tingkat keyakinan diri dalam merawat anaknya yang lebih tinggi. Keberhasilan konseling dapat dipengaruhi oleh tingkat pendidikan karena pendidikan dapat mempengaruhi cara pandang seseorang terhadap informasi baru yang diterimanya. Semakin tinggi tingkat pendidikannya, semakin mudah seseorang menerima informasi yang didapatkannya. Namun, pemberian konseling balita diare dengan bantuan media konseling dapat meningkatkan penyerapan informasi yang disampaikan sehingga responden berpendidikan rendah dapat dengan mudah menerima informasi yang didapatkan.

Tingkat pendidikan subjek tidak terlalu berbeda pada kedua kelompok penelitian, artinya subjek mempunyai kemampuan yang 
sama dan seimbang dalam menerima, menganalisis suatu informasi baru seperti prinsip penanganan balita diare tanpa dehidrasi dan menyimpannya dalam ingatan. Kemampuan analisa subjek juga dibutuhkan untuk menirukan praktik atau kegiatan sehingga subjek dapat melakukan suatu kegiatan atau perilaku yang sama, dalam penelitian ini diharapkan ibu balita mampu melakukan penanganan balita diare tanpa dehidrasi dengan tepat dan efektif agar terhindar dari komplikasi.

Pekerjaan responden didominasi ibu rumah tangga atau tidak bekerja pada kedua kelompok penelitian. Kondisi dimana ibu balita yang tidak bekerja memiliki peluang yang lebih besar dalam melakukan penanganan balita diare tanpa dehidrasi dirumah karena ibu memiliki banyak waktu dirumah dibandingkan dengan ibu yang bekerja.

Penghasilan dan pengetahuan responden pada kedua kelompok tidak terdapat perbedaan secara bermakna, artinya pengetahuan yang didapat akan membuat ibu lebih sadar akan kondisi balitanya sehingga dengan adanya perubahan perilaku penanganan mencegah pengeluaran materi dan psikologis yang lebih dikomunitas.

Gambaran karakteristik bidan yang ditunjukkan pada tabel 2 terdapat bahwa tidak ada perbedaan yang bermakna pada kedua kelompok penelitian, yang ditunjukkan oleh nilai $\mathrm{p}$ hasil uji chi-kuadrat melebihi 0,05 sehingga dapat disimpulkan bahwa kedua kelompok memiliki karakteristik yang homogen sehingga layak untuk diperbandingkan.

\section{Pengaruh Keterampilan Bidan Konseling Berdasar Health Belief Model (HBM) Terhadap Perubahan Perilaku Penanganan Balita Diare Tanpa Dehidrasi.}

Penerapan konseling dengan HBM dalam perubahan perilaku diaplikasikan awalnya pada perubahan perilaku seksual berisiko yang dilakukan lewat metode konseling, dimana dengan adanya konseling akan resiko dan bahaya dari perilaku seksual dapat meningkatkan perubahan persepsi dan perlakuan untuk meminimalisir resiko seksual tersebut dan melakukan tindakan pencegahan untuk tidak mudah terkena risiko tersebut.(Kapti, 2013) Health Belief Model (HBM) ini memfasilitasi konseling dengan menggali persepsi kerentanan dan keparahan, persepsi isyarat, efikasi diri, persepsi manfaat dan persepsi hambatan agar terbentuk perilaku sehat dengan harapan subjek penelitian dapat terjaga kesehatannya.

Berdasarkan kajian HBM sebelumnya yang mempunyai kemiripan dengan kasus balita diare tanpa dehidrasi. Dalam hal ini ibu balita diare tanpa dehidrasi membutuhkan informasi penanganan balita diare tanpa dehidrasi yang tepat dan dapat mencegah pada keadaan yang berisiko lebih buruk. Konseling berdasar HBM ini digunakan pada ibu balita diare tanpa dehidrasi.

Sebelum penelitian dilaksanakan, peneliti melakukan pelatihan konseling berdasar HBM pada bidan dan enumerator dipuskesmas perlakuan. Bidan dan enumerator kemudian melakukan konseling berdasar HBM yang terjadwal pada subjek penelitian untuk meningkatkan persepsi kerentanan dan keparahan, persepsi isyarat, efikasi diri, persepsi manfaat dan persepsi hambatan.

Proses konseling yang terlalu lama terkadang membuat ibu balita tidak bisa berkonsentrasi dalam mengikuti konseling balita diare tanpa dehidrasi. Dalam mengatasi hal tersebut peneliti melatih bidan (enumerator) yang tidak bekerja di puskesmas untuk memberikan konseling berdasar HBM dirumah agar proses konseling dapat berjalan.

Perubahan perilaku terjadi akibat hasil dari intervensi atau adanya pembelajaran dari peristiwa yang dapat mengurangi atau menggerakan fisiologis seseorang dan perubahan perilaku juga terjadi dengan adanya frekuensi yang berulang dalam pemberian informasi (reinforcements) dan 
hal ini juga dipengaruhi dengan adanya reward/penghargaan atas apa yang telah dilakukan.(Glanz, 2008)

Untuk meningkatkan perilaku ibu dalam merawat balitanya yang sakit WHO merancang strategi dalam pendidikan kesehatan yang berupa konseling. Konseling disini merupakan suatu upaya untuk menciptakan perilaku masyarakat yang kondusif bagi kesehatan. Artinya konseling yang ditujukan pada ibu dapat menciptakan perilaku yang kondusif untuk kesehatan anaknya. Hal ini sesuai dengan penelitian yang dilakukan tahun 2012 dimana hasilnya pemberian konseling pada ibu berpengaruh terhadap perilaku ibu dalam merawat balita sakit diare.(Puspitasari, 2012)

Berdasarkan hasil penelitian yang ditunjukkan pada tabel 4 didapatkan pada awal penelitian tidak ada perbedaan bermakna pada kelompok perlakuan dan kelompok kontrol dalam perilaku penanganan balita diare tanpa dehidrasi. Analisis lebih lanjut didapatkan bahwa setelah penelitian nilai kedua kelompok berbeda secara bermakna $(p<0,05)$ terhadap perubahan perilaku penanganan balita diare tanpa dehidrasi.

Pada tabel 4 didapatkan bahwa perubahan perilaku penanganan pada ibu balita yang mendapatkan konseling berdasar HBM secara bermakna lebih tinggi $(\mathrm{p}<0,05)$. Peningkatan perilaku penanganan terhadap balita diare tanpa dehidrasi pada kelompok perlakuan lebih tinggi $39,9( \pm 9,2)$ bila dibandingkan dengan kelompok kontrol $2,5( \pm 2,5)$.

Hasil penelitian ini juga mungkin dapat dipengaruhi keterampilan konseling bidan yang ditunjukkan pada tabel 3 dimana terdapat perbedaan yang signifikan $(\mathrm{p}<0,05)$ dimana ada perbedaan keterampilan konseling antara kedua kelompok yang mana kelompok perlakuan diberikan pelatihan konseling berdasar Health Belief Model (HBM) lebih tinggi $67,4( \pm 19,7)$ dibandingkan kelompok kontrol konseling yang diterapkan sebatas reinforcement konseling standar saja $8,2( \pm 5,4)$.
Perubahan perilaku ibu pada penelitian ini dapat dipengaruhi juga oleh perubahan persepsi ibu dimana ibu yang telah dikonseling pada kelompok perlakuan mengalami peningkatan persepsi dimana ibu merasa penting akan melakukan penanganan balita diare dengan selalu memantau kondisi anaknya yang bisa saja mengalami keadaan yang berisiko menjadi komplikasi, asumsi ini didapat berdasarkan wawancara pada saat ibu melakukan pengisian kuesioner, dimana hampir semua ibu berasumsi bahwa diare merupakan penyakit yang rentan akan risiko pada keadaan yang lebih buruk jika tidak ditangani secara tepat.

Menurut Karen (2009) dalam penelitiannya menunjukkan bahwa intervensi dengan memberikan edukasi memiliki efek besar dalam meningkatkan penanganan balita diare. Konseling berdasar HBM merupakan rangkaian-rangkaian kontak atau hubungan secara langsung dengan individu yang tujuannya memberikan bantuan dalam merubah sikap dan tingkah laku. Dalam proses konseling bidan memberikan edukasi tentang seputar balita diare tanpa dehidrasi dan mengatasi masalah yang dialami ibu balita dalam penanganan balita diare tanpa dehidrasi.

Pada penelitian ini penggunaan media dalam konseling membantu menghindari kesalahan bicara pada konselor dan sebagai alat bantu untuk menyampaikan informasi yang relevan seputar penanganan balita diare tanpa dehidrasi sehingga keyakinan diri ibu dalam melakukan penanganan meningkat dimana ibu sangat yakin bisa melakukan perawatan balita diare tanpa dehidrasi dirumah.

Untuk dapat menjamin pelayanan konseling perlu didukung sarana penunjang. Sarana yang perlu diperhatikan yaitu ruangan tempat pelaksanaan konseling harus nyaman dan didukung dengan sarana bahan penunjang konseling yang sesuai. Media yang digunakan sebagai alat bantu konseling pada penelitian ini yaitu lembar balik yang diberikan pada ibu untuk dibawa pulang sebagai bentuk informasi tentang pentingnya 
penanganan balita diare tanpa dehidrasi dan komplikasi yang akan terjadi jika kurang tepatnya penanganan diare yang dapat dibaca berulang dirumah dan pemutaran vidio sebagai alat bantu visual pada bidan dalam penyampaian informasi yang berisi tentang ilustrasi secara audio dan visual bagaimana proses dan langkah penanganan balita diare tanpa dehidrasi. Seseorang belajar melalui panca inderanya. Setiap indera ternyata berbeda pengaruhnya terhadap hasil belajar seseorang. Oleh karena itu seseorang dapat mempelajari sesuatu dengan baik apabila ia menggunakan lebih dari satu indera.

Proses konseling merupakan proses bantuan yang diberikan oleh seseorang yang berprofesi dibidang konseling kepada individu yang memiliki kesulitan dan biasa dilakukan dengan cara face to face, sehingga individu yang mendapat bantuan tersebut mendapat kebahagiaan. Pemberian bantuan face to face dalam proses konseling tentu saja membutuhkan teknik dan keterampilan tertentu yang harus dikuasai.

Seorang petugas yang terampil adalah petugas kesehatan yang telah dididik dan dilatih seperti bidan, dokter atau perawat untuk menguasai keterampilan-keterampilan yang dibutuhkan untuk mengelola balita diare tanpa dehidrasi dan melakukan identifikasi, manajemen dan rujukan dari komplikasi pada ibu balita dengan diare tanpa dehidrasi.

Pada penelitian dengan metode berdasar HBM ini secara evaluasi masih belum sempurna, penelitian sebatas melihat keterampilan konseling berpengaruh pada perubahan perilaku ibu. Masih banyak lagi yang dapat dievaluasi, ada baiknya menjadi pertimbangan lebih lanjut untuk instansi kesehatan dalam pengembangan pelatihan konseling dan pada institusi pendidikan untuk dapat melakukan penelitian lebih lengkap lagi terkait pengembangan model konseling berdasar HBM.

\section{KESIMPULAN}

\section{Simpulan Umum}

Keterampilan bidan konseling berdasar Health Belief Models (HBM) pada ibu balita dapat merubah perilaku penanganan balita diare tanpa dehidrasi.

\section{Simpulan Khusus}

Perubahan perilaku penanganan balita diare tanpa dehidrasi pada kelompok yang diberi konseling berdasar Health Belief Models (HBM) rata rata lebih tinggi sebesar 39,9.

\section{DAFTAR PUSTAKA}

Beck RS, Daughtridge R, Sloane PD. 2002. Physician-Patient Communication In The Primary Care Office: A Systematic Review. The Journal Of The American Board Of Family Practice.

Dinas Kesehatan Sumatera Selatan. 2013. Profil Kesehatan Provinsi Sumatera Selatan Tahun 2010. Dinkes Provinsi Sumatera Selatan, Palembang.

Dinas Kesehatan Kota Palembang. 2014. Profil Kesehatan Kota Palembang Tahun 2013. Palembang.

Fadel C, Lemke C. 2008. Multimodal Learning Through Media: What The Research Says. San Jose, CA: Cisco Systems.

Glanz K, Rimer BK, Viswanath K. 2008. Health Behavior And Health Education: Theory, Research, And Practice: John Wiley \& Sons.

Kapti RE, Rustina Y, Widyatuti W. 2013. Efektifitas Audiovisual Sebagai Media Penyuluhan Kesehatan Terhadap Peningkatan Pengetahuan Dan Sikap Ibu Dalam Tatalaksana Balita Dengan Diare Di Dua Rumah Sakit Kota Malang. Jurnal Ilmu Keperawatan. 
Kemenkes RI. 2011. Pedoman Pembinaan Perilaku Hidup Bersih Dan Sehat (PHBS). Jakarta: Pusat Promosi Kesehatan, Kementerian Kesehatan RI.

Kemenkes RI. 2011. Situasi Diare Di Indonesia. Buletin Jendela Data Dan Informasi Kesehatan.

Kemenkes RI. 2011. Panduan Sosialisasi Tatalaksana Diare Balita. Jakarta: Direktorat Jenderal Pengendalian Penyakit Dan Penyehatan Lingkungan.

Kemenkes RI. 2013. Riset Kesehatan Dasar. Jakarta: Badan Penelitian Dan Pengembangan Kesehatan Departemen Kesehatan Republik Indonesia.

Kusuma AB. 2009. Keefektifan Konseling Kepada Ibu Terhadap Perilaku Hidup Bersih Sehat Dan Kejadian Diare Akut Anak Balita Di Puskesmas Serayu Larangan Kabupaten Purbalingga. Universitas Sebelas Maret.

Mcleod J. 2016. Pengantar Konseling: Teori Dan Studi Kasus. Ketiga Ed. Jakarta; Jakarta Kencana.

Maryunani A. 2017. Ilmu Kesehatan Anak Dalam Kebidanan. Jakarta: Trans Info Media.

Mengistie B, Berhane Y, Worku A. 2013. Prevalence Of Diarrhea And Associated Risk Factors Among Children UnderFive Years Of Age In Eastern Ethiopia: A Cross-Sectional Study. Open Journal Of Preventive Medicine.

Mola O, Mercer M, Asghar R, Gimbel-Sherr $\mathrm{K}$, Gimbel-Sherr S, Micek M, Et Al. 2016. Condom Use After Voluntary Counselling And Testing In Central Mozambique. Tropical Medicine \& International Health.
Nhampossa T, Mandomando I, Acacio S, Quintó L, Vubil D, Ruiz J, Et Al. 2015. Diarrheal Disease In Rural Mozambique: Burden, Risk Factors And Etiology Of Diarrheal Disease Among Children Aged 0-59 Months. Seeking Care At Health Facilities. Plos One.

O'Reilly CE, Jaron P, Ochieng B, Nyaguara A, Tate JE, Parsons MB, Et Al. 2012. Risk Factors For Death Among Children Less Than 5 Years Old Hospitalized With Diarrhea In Rural Western Kenya, 2005-2007: A Cohort Study. Plos Med.

Nuraeni A. 2012. Hubungan Penerapan PHBS Keluarga Dengan Kejadian Diare Balita Di Kelurahan Tawangmas Kota Semarang. Tesis. Depok: Fakultas Ilmu Keperawatan Universitas Indonesia.

Puspitasari A. 2012. Pengaruh Konseling Dalam Manajemen Terpadu Balita Sakit (MTBS) Terhadap Perilaku Ibu Dalam Merawat Balita Sakit Dengan Diare Di Puskesmas Biyungan Bantul.

Riauwi HM. 2014. Efektivitas Pendidikan Kesehatan Dengan Penerapan The Health Belief Model Terhadap Pengetahuan Keluarga Tentang Diare. Jurnal Online Mahasiswa Bidang Ilmu Keperawatan.

Seguin M, Niño Zarazúa M. 2015. Non-Clinical Interventions For Acute Respiratory Infections And Diarrhoeal Diseases Among Young Children In Developing Countries. Tropical Medicine \& International Health. 
